\title{
The Performance of Anaerobic Co-digester of Swine Slurry and Food Waste
}

\author{
Young-Man Yoon, Hyun-Cheol Kim, Jung-Suk Yoo, Seung-Hwan Kim, \\ Seung-Gil Hong ${ }^{1}$, and Chang-Hyun Kim*
}

\author{
Biogas Research Center, Hankyong National University, Anseong, Gyeonggi, 456-749, Republic of Korea \\ ${ }^{I}$ National Academy of Agricultural Science, R.D.A., Suwon, Gyeonggi, 441-707, Republic of Korea
}

In order to assess the performance of co-digester using pig sluny and food waste at the farm scale biogas production facility, the anaerobic facility that adopts the one-stage CSTR of $5 \mathrm{~m}^{3} \mathrm{day}^{-1}$ input scale was designed and installed under the conditions of the OLR of $2.33 \mathrm{~kg} \mathrm{~m}^{-3}$ day $^{-1}$ and HRT of 30 days in an pig farmhouse. Several operation parameters were monitored for assessment of the process performance. The anaerobic facility was operated in three stages to compare the performance of the anaerobic co-digester. In the Stage I, that was fed with a mix of pig sluny to food waste ratio of 7:3 in the input volume, where input TS content was $4.7( \pm 0.8) \%$, and OLR was $0.837-1.668 \mathrm{~kg}^{-} \mathrm{VS} \mathrm{m}^{-3} \mathrm{day}^{-1}$. An average biogas yield observed was $252 \mathrm{Nm}^{3} \mathrm{day}^{-1}$ with methane content $67.9 \%$. This facility was capable of producing an electricity of 626 $\mathrm{kWh} \mathrm{day}^{-1}$ and a heat recovery of $689 \mathrm{Mcal}^{-1} \mathrm{day}^{-1}$. In Stage II, that was fed with a mixture of pig slury and food waste at the ratio of $6: 4$ in the input volume, where input TS content was $6.9( \pm 1.9) \%$, and OLR was

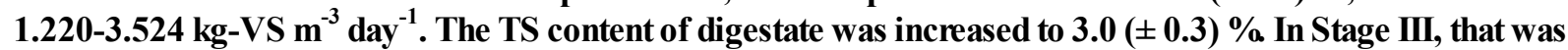
fed with only pig slurry, input TS content was $3.6( \pm 2.0) \%$, and OLR was $0.182-2.187 \mathrm{~kg}^{-V S ~ m} \mathrm{may}^{-1}$. In stage III, TS and volatile solid contents in the input pig slurry were highly variable, and input VFAs and alkalinity values that affect the performance of anaerobic digester were also more variable and sensitive to the variation of input organic loading during the digester operation. The biogas produced in the stage III, ranged from 11.3 to $170.0 \mathrm{~m}^{3} \mathrm{day}^{-1}$, which was lower than $222.5-330.2 \mathrm{~m}^{3} \mathrm{day}^{-1}$ produced in the stage II.

Key words: Anaerobic co-digestion, Pig slurry, Food waste, Performance, Organic loading

\section{Introduction}

In the aspect of climate change, livestock wastes contribute about $18.7 \%$ of the agricultural portion to the greenhouse gas emissions in Korea. Recently, anaerobic fermentation technology of livestock wastes is becoming a feasible technology to be adopted for the agricultural recycling of livestock wastes since methane production from livestock wastes may have an important role in reducing the impact of the agriculture on the environment. Livestock manure from concentrated livestock operations can be a source of energy production that not only provides an alternative energy source for on-farm use, but mitigates the negative consequences of odor from livestock operations. On the other hand, the natural degradation of livestock wastes during the storage leads to the release of greenhouse

\footnotetext{
Received : November 12. 2010 Accepted : November 19. 2010 *Corresponding author : Phone: +82316705095

E-mail: kimch@hknu.ac.kr
}

gases to the atmosphere. But, in order to install and operate a biogas production facility at farm scale, feasibility is to be assessed in the technical and economical aspects before installation and the suitable design must be devised in the consideration of the digester loading and the energy generated from the system because the anaerobic facility must be designed to meet the typical characteristics of each farm (Yoon et al., 2009 $)$.

Anaerobic digester for the biogas production of animal manure has been commonly adopted with CSTR or PFR (Wilkie et al., 2004). In order to improve the economical efficiency of biogas facility, the amount of energy produced per unit manure treated should be maximized while the investment and operation costs should be minimized (Karakashev et al., 2005). In the technical aspect, several methods for improving biogas production from livestock wastes in the CSTR and PFR processes have been reported by co-digestion with other organic materials (Angelidaki and Ellegaard, 2003; Paavola et al., 2006), adopting of alternative digester configuration (Speece et al., 1997; 
Azbar et al., 2001; Angelidaki et al., 2005), increment of HRT, reducing the ammonia toxicity (Hansen et al., 1998), and improvement of degradability by pre-treatment (Ahring and Angelidaki, 2000; Hartmann et al., 2000).

Swine manure is one of the main substances that is used in Korean farm scale biogas plant. Generally the high amount of pig manure is discharged as slurry phase that have a small fraction around $1-7 \%$ of TS from pig farmhouse, since most of Korean pig farmhouses have been adopting the slurry storage tank without a solid/ liquid separation equipment (Yoon et al., 2009 ${ }^{\mathrm{b}}$ ). The fluctuation of organic contents in pig slurry discharged from the farmhouse may cause "wash-out" that methane producing bacteria are lost in anaerobic digester which disturbs microbial community of the anaerobic digester and consequently methane yield decreases steeply (Yu et al., 2005; Boe and Angelidaki, 2009). Co-digestion is a technology that increasingly being applied for simultaneous treatment of several solid and liquid organic wastes (Poggi-Varaldo et al., 1997; Callaghan et al., 1999; Bouallagui et al., 2009). Co-digestion combining different organic substances as input feedstock, can increase process performance by the improvement of stability of anaerobic microbial community and the sustenance of high organic loading at anaerobic digester (Zhang and Banks, 2008).

This study was carried out to assess the performance of anaerobic digester when a pig slurry discharged from farmhouse in a high organic fluctuation, and a food waste having a high organic content were co-digested. Using the pilot scale, $5 \mathrm{~m}^{3}$ day $^{-1}$, CSTR type anaerobic digester, the performance of anaerobic co-digester was demonstrated in the several operational stages that had been operated in different organic loadings. Digestion of single pig slurry was investigated in the separate operation period to assess the effect of co-digestion.

\section{Material and Methods}

Pilot scale CSTR anaerobic digester The pilot scale anaerobic facility that was adopting a one stage CSTR (Continuously Stirred Tank Reactor) of $5 \mathrm{~m}^{3}$ day $^{-1}$ input scale and a dual fuel type CHP (Combined Heat \& Power) generator of $30 \mathrm{~kW}$, was installed at a Korean pig farm in Jan 2008. The system setup of anaerobic facility is shown in Fig. 1. Food waste that is transferred with (14) tank lorry and pig slurry discharged from pig pan was mixed in (2) feedstock mix \& storage tank (total volume, $30 \mathrm{~m}^{3}$ ),

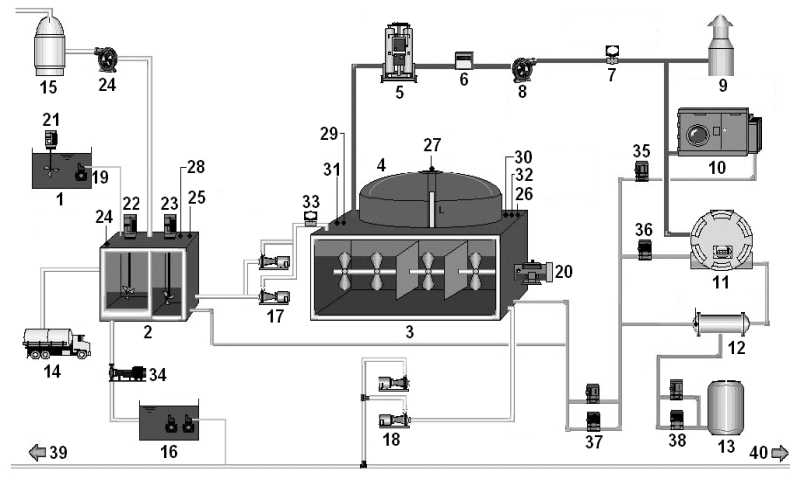

Fig. 1. Process scheme; (1) Pig sluny storage tank; (2) Feedstock mix \& storage tank; (3) Anaerobic digester (L10 $\times$ H4.25 $\times$ W4.25 m, $180 \mathrm{~m}^{3}$ ); (4) Biogas bag; (5) Dehumidification \& desulfurization unit; (6) Gas meter; (7) Gas transfer pump; (8) Gas flow meter; (9) Gas bumer; (10) Dual fuel CHP generator; (11) Gas boiler; (12) Header tank for hot-water heating; (13) Water tank; (14) Tank lony for food waste transfer; (15) Deodorization unit; (16) Sump pit; (17) Feeding pump[in parallel]; (18) Digestate transfer pumper[in parallel]; (19) Pig slumy transfer pump; (20-21-22-23) Mixer, (24-25-26) Level sensor, (27) Ultrasonic gas bag level sensor; (28-29-30) Temperature sensor; (3132) pH sensor; (33) feed flow meter; (34) Sump screw pump; (35-36-37) Hot water circulation pump; (38) Header water supply pump; (39) Water treatment system; (40) Liquid fertilizer storage tank.

and prepared mixed feedstock was inputted to (3) pilot scale CSTR anaerobic digester (total volume, $180 \mathrm{~m}^{3}$ ). The biogas evolved from the anaerobic digester was reserved in (4) a biogas bag (max. volume $80 \mathrm{~m}^{3}$ ), and the hydrogen sulfide gas present in the biogas was removed first by the biological sulfur oxidation reaction with air input method. The remaining hydrogen sulfide and moisture were removed by (5) dehumidification \& desulfurization unit adopted to tamping unit of active carbon and the cooling unit decreasing the temperature to below dew point. The purified biogas was blown to (10) dual fuel CHP generator. After electric generation, the waste heat evolved by the exhausting gas of generator was collected as hot water by heat exchanger installed in CHP generator. The hot water was used for digester heating.

For the monitoring and maintenance of the anaerobic facility; $\mathrm{pH}$, temperature and water level sensors were installed in the inner side of (3) anaerobic digester, and ultrasonic gas bag level sensor and gas meter (SSM 6000, PRONOVA) were fitted in the upper side of (4) biogas bag and on the pipe line after (5) dehumidification \& desulfurization unit. All sensing data were recorded in a data logger. For the monitoring of the operation conditions 
Table 1. Chemical composition of feedstock for the design of the pilot scale CSTR anaenobic digester.

\begin{tabular}{|c|c|c|}
\hline Parameter & Pig slurry & Food waste \\
\hline $\mathrm{pH}$ & $7.5(0.5)^{\dagger}$ & $4.3(0.2)$ \\
\hline $\mathrm{TS}\left(\mathrm{mg} \mathrm{L}^{-1}\right)$ & $46,300(17,800)$ & $19,000(8,900)$ \\
\hline VS (mg L $\left.{ }^{-1}\right)$ & $32,000(15,000)$ & $154,300(29.100)$ \\
\hline $\mathrm{SS}\left(\mathrm{mg} \mathrm{L}{ }^{-1}\right)$ & $30,100(15,700)$ & $75,000(55,900)$ \\
\hline $\mathrm{TN}\left(\mathrm{mg} \mathrm{L}^{-1}\right)$ & $3,500(1,600)$ & $3,600(600)$ \\
\hline $\mathrm{TP}\left(\mathrm{mg} \mathrm{L}^{-1}\right)$ & $1,000(500)$ & $500(300)$ \\
\hline $\mathrm{NH}_{4}^{+}-\mathrm{N}\left(\mathrm{mg} \mathrm{L}^{-1}\right)$ & $3,100(800)$ & $400(200)$ \\
\hline $\mathrm{TCOD}_{\mathrm{Cr}}\left(\mathrm{mg} \mathrm{L}^{-1}\right)$ & $60,400(14,400)$ & $206,100(24,100)$ \\
\hline $\operatorname{SCOD}_{\mathrm{Cr}}\left(\mathrm{mg} \mathrm{L}^{-1}\right)$ & $31,700(10,300)$ & $87,300(5,600)$ \\
\hline $\mathrm{BOD}_{5}\left(\mathrm{mg} \mathrm{L}^{-1}\right)$ & $34,500(9,800)$ & $138,300(25,500)$ \\
\hline
\end{tabular}

${ }^{\dagger}$ Standard deviation.

Table 2. Design factors of the pilot scale CSTR anaerobic digester.

\begin{tabular}{|c|c|c|c|}
\hline Parameters & Pig slurry & Food waste & Total \\
\hline Input amount $\left(\mathrm{m}^{3}\right.$ day $\left.^{-1}\right)$ & 3.5 & 1.5 & 5.0 \\
\hline $\mathrm{TS}\left(\mathrm{mg} \mathrm{L}^{-1}\right)$ & 46,000 & 190,000 & 89,000 \\
\hline $\operatorname{VS}\left(\mathrm{mg} \mathrm{L} \mathrm{L}^{-1}\right)$ & 32,000 & 154,000 & 69,000 \\
\hline VS removal $(\%)$ & 40 & 60 & 53 \\
\hline Methane content $(\%)$ & 62 & 60 & 60 \\
\hline Biogas production $\left(\mathrm{Nm}^{3}\right.$ day $\left.^{-1}\right)$ & 42 & 157 & 199 \\
\hline
\end{tabular}

of CSTR anaerobic digester, three sampling ports were prepared in the fore, middle and end part of CSTR anaerobic digester.

Design of anaerobic co-digester The CSTR anaerobic digester was designed with the co-digestion system using pig slurry (70\%) and food wastes (30\%). The chemical characteristics of pig slurry and food waste that were sampled and analyzed for the design of pilot scale CSTR anaerobic reactor was shown in Table 1. The pilot scale CSTR anaerobic digester was constructed with the concrete structure having an effective volume of $150 \mathrm{~m}^{3}$ and OLR (organic loading rate) and HRT (hydraulic retention time) of $2.33 \mathrm{~kg}-\mathrm{VS} \mathrm{m}^{-3}$ day $^{-1}$ and 30 days, respectively. Operation temperature of digester was maintained at $38^{\circ} \mathrm{C}$ by the circulation of hot water obtained from the heat exchanger of CHP generator. The design factors of pilot scale CSTR anaerobic digester is shown in Table 2.

Operation The pig slurry was obtained from pig farm in the pilot scale CSTR with anaerobic facility installed, and the pulverized food waste was transported by a tank lorry from the local food waste treatment plant. The

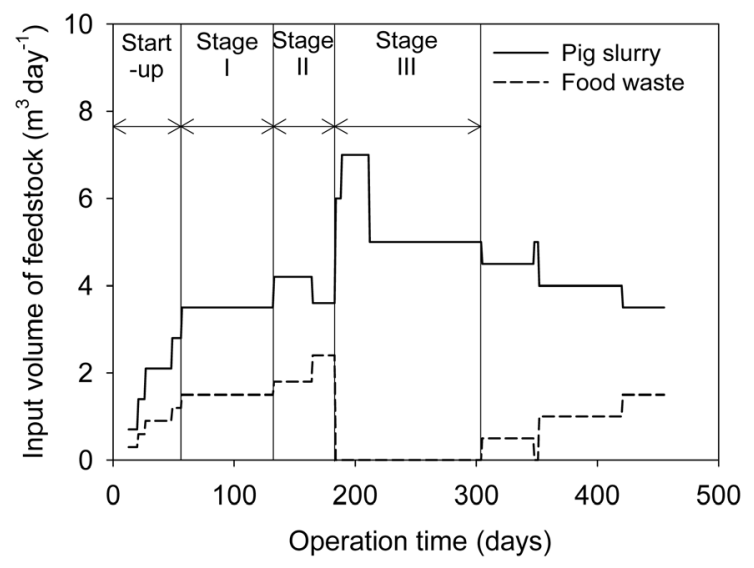

Fig. 2. Operation schedule of the pilot scale CSTR anaerobic digester.

experiment was carried out for a period of 399 days. The anaerobic reactor was operated with a liquid working volume of $150 \mathrm{~m}^{3}$ (total digester volume $180 \mathrm{~m}^{3}$ ) and an HRT of 30 days at $38 \pm 2.0^{\circ} \mathrm{C}$ during winter season. Including the time for the seeding and warming of anaerobic digester, the start-up of operation has been progressed by stepwise increasing the input volume of food waste to $30 \%$ of total input volume for 56 days. During the initial 76 days (Stage I) of operation, the pig 
slurry mixed with $30 \%$ of food waste was fed to digester. During the second period of 51 days (Stage II), the mixing ratio of food waste was increased to $40 \%$. For the last 121 days (Stage III), simple pig slurry without the mixing of food waste was introduced to digester. After the Stage III, the anaerobic digester was operated in the various mixing condition for 151 days. The operation stages during the experiment are shown in Fig. 2.

Analytical methods The pig slurry and food waste incoming to the pilot scale anaerobic facility was sampled in every delivery. The $\mathrm{pH}$, VFAs, alkalinity, TS, VS and ammonium nitrogen $\left(\mathrm{NH}_{4}{ }^{+}-\mathrm{N}\right)$ were determined by a periodic analysis. For the monitoring of anaerobic digester, five samples from the feedstock storage tank, the anaerobic digester (the fore, middle and end part of digester) and the outlet of anaerobic digester were taken on daily basis, and were stored at $-4^{\circ} \mathrm{C}$ till analysis. Process parameters such as $\mathrm{pH}$, VFAs, alkalinity, TS, VS and ammonium nitrogen $\left(\mathrm{NH}_{4}{ }^{+}-\mathrm{N}\right)$ were determined. Biogas production, composition and the temperature of digester were monitored through the data logger. The $\mathrm{pH}$, alkalinity, TS, VS and ammonium nitrogen $\left(\mathrm{NH}_{4}{ }^{+} \mathrm{N}\right)$ were determined according to the standard methods (APHA, 1998). The VFAs (acetic, propionic, butyric, isobutyric, valeric, and isovaleric acid) were measured by GC with FID (Sorensen et al., 1991) The biogas was sampled in the biogas bag of the pilot scale CSTR anaerobic facility periodically (twice a month) to analyze methane content by GC TCD for the verification of the data gathered from the data logger.

\section{Results}

Seasonal changes of organic content in pig slurry and food waste are shown in Fig. 3. The TS and VS contents of pig slurry discharged from pig pan were monitored from May, 2008 to April, 2009. Range of organic content in pig slurry showed a high fluctuations (TS 2.30-6.66, VS 1.32$5.60 \%$ ) according to the seasonal change, especially solid content increased in winter season; on the other hand, the values decreased in summer season due to the increase of water use in pig pan. Range of organic content in food waste coming to the pilot scale anaerobic facility showed relatively low variations in TS (12.30-13.87\%) and VS (10.47-12.11\%).

In the each operation stage, operation parameters and biogas yields ware shown in Table 3 and 4. After the

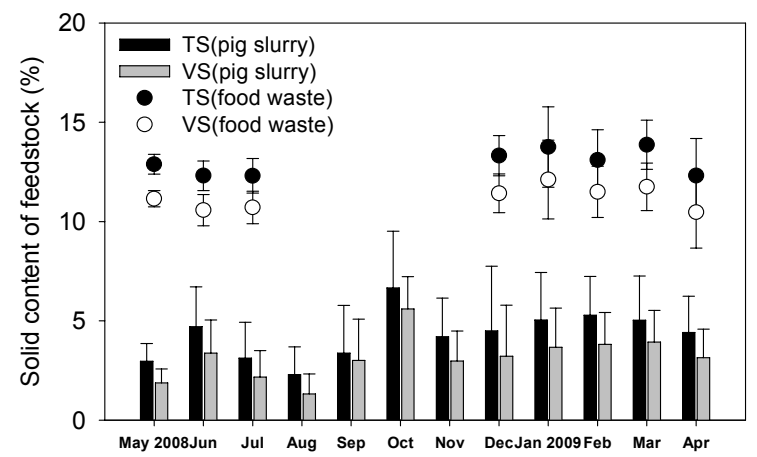

Fig. 3. Seasonal changes of organic content in pig slurry and food waste incoming to the pilot scale anaerobic facility. Vertical bars mean the standard deviations of each mean values.

Table 3. Operational characteristics of feed and digestate in the pilot scale CSTR anaerobic digester.

\begin{tabular}{lcccccc}
\hline \hline \multirow{2}{*}{ Items } & \multicolumn{2}{c}{ Stage I $^{\dagger}$} & \multicolumn{2}{c}{ Stage I } & \multicolumn{2}{c}{ Stage III $^{\S}$} \\
\cline { 2 - 6 } & Feed & Digestate & Feed & Digestate & Feed & Digestate \\
\hline \multirow{2}{*}{$\mathrm{pH}$} & 6.23 & 8.02 & 5.51 & 7.95 & 7.72 & 7.92 \\
& $(0.37)^{\uparrow}$ & $(0.07)$ & $(0.26)$ & $(0.07)$ & $(1.02)$ & $(0.95)$ \\
TS (mg L & 46,923 & 25,818 & 69,959 & 30,052 & 35,546 & 25,301 \\
& $(7,955)$ & $(2,720)$ & $(19,100)$ & $(2,500)$ & $(20,964)$ & $(7,119)$ \\
VS (mg L & 35,211 & 15,485 & 55,578 & 17,401 & 24,894 & 14,961 \\
& $(6,840)$ & $(4,184)$ & $(16,437)$ & $(2,033)$ & $(17,059)$ & $(5,195)$ \\
TVFAs (mg L & 16,102 & 854 & 17,801 & 1,207 & 5,145 & 356 \\
& $(4,731)$ & $(152)$ & $(3,040)$ & $(169)$ & $(2,891)$ & $(163)$ \\
Alkalinity (mg L & 9,474 & 16,373 & 8,951 & 18,456 & 13,602 & 15,801 \\
& $(1,640)$ & $(585)$ & $(2651)$ & $(799)$ & $(4,541)$ & $(3,217)$ \\
\hline
\end{tabular}

${ }^{\dagger}$ Stage I feed the mix of pig slurry and food waste as the volume ratio of $7: 3$.

${ }^{\ddagger}$ Stage II feed the mix of pig slurry and food waste as the volume ratio of $6: 4$.

${ }^{\S}$ Stage III feed only pig slurry.

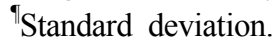


Table 4. Performance of the pilot scale CSTR anaerobic digester.

\begin{tabular}{llll}
\hline \hline Items & Stage I & Stage II $^{\ddagger}$ & Stage $^{\dagger}$ III $^{\S}$ \\
\hline $\mathrm{CH}_{4}$ concentration $(\%)$ & $65.6 \sim 69.8$ & $61.4 \sim 68.0$ & $62.3 \sim 75.8$ \\
Biogas production $\left(\mathrm{m}^{3}\right.$ day $\left.^{-1}\right)$ & $120.0 \sim 345.0$ & $222.5 \sim 330.2$ & $11.3 \sim 170.0$ \\
OLR $\left(\mathrm{kg}-\mathrm{VS} \mathrm{m}{ }^{-3}\right.$ day $\left.^{-1}\right)$ & $0.837 \sim 1.668$ & $1.220 \sim 3.524$ & $0.182 \sim 2.187$ \\
\hline
\end{tabular}

${ }^{\dagger}$ Stage I feed the mix of pig slurry and food waste as the volume ratio of 7:3.

${ }^{\ddagger}$ Stage II feed the mix of pig slurry and food waste as the volume ratio of $6: 4$.

${ }^{\S}$ Stage III feed only pig slurry.

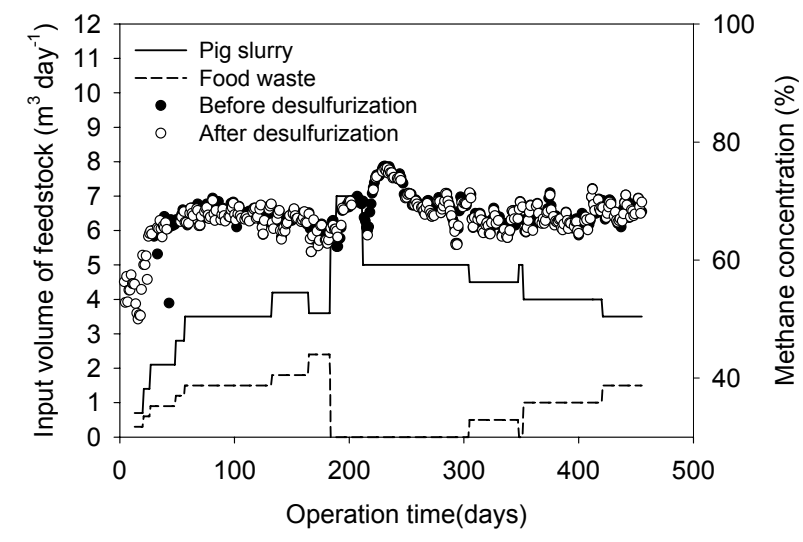

Fig. 4. Variation of methane content in biogas produced from the pilot scale CSTR anaerobic digester.

start-up of 56 days, during the operation time of Stage I (76 days), OLR was in the range of $0.837-1.668 \mathrm{~kg}^{-} \mathrm{VS} \mathrm{m} \mathrm{m}^{-3}$ day $^{-1}$. Biogas of 120.0-345.0 $\mathrm{m}^{3}$ day $^{-1}$ was produced with the methane percentage $(\mathrm{mol} / \mathrm{mol})$ of $65.6-69.8 \%$. During the operation time of Stage II (51 days), OLR was in the range of 1.220-3.524 kg-VS m ${ }^{-3}$ day $^{-1}$. Biogas of 222.5$330.2 \mathrm{~m}^{3}$ day $^{-1}$ was produced with the methane percentage of 61.4-68.0\%. In the Stage III (151 days), OLR was in the range of $0.182-2.187 \mathrm{~kg}-\mathrm{VS} \mathrm{m}^{-3}$ day $^{-1}$. Biogas of 11.3$170.0 \mathrm{~m}^{3}$ day $^{-1}$ was produced with the methane percentage of $62.3-75.8 \%$. In each of the operation stages, TVFAs of anaerobic digester was maintained at $854 \pm 152,1,207 \pm$ 169 , and $356 \pm 163 \mathrm{mg} \mathrm{L}^{-1}$, respectively, and the concentrations of TVFAs of anaerobic digester were increased with the organic input loading rate $\left(\mathrm{kg}-\mathrm{VS} \mathrm{m} \mathrm{m}^{-3} \mathrm{day}^{-1}\right)$. During the third operation stage that was fed only pig slurry, TS and VS contents in the incoming pig slurry were in high variations, and also TVFAs and alkalinity values that affected on the performance of anaerobic digester were highly fluctuated. Fig. 4 and 5 were showing the changes of methane concentration and biogas production during total operation period, respectively. The input of food waste as feedstock resulted in the gradual decrease of methane content during the experimental period, while

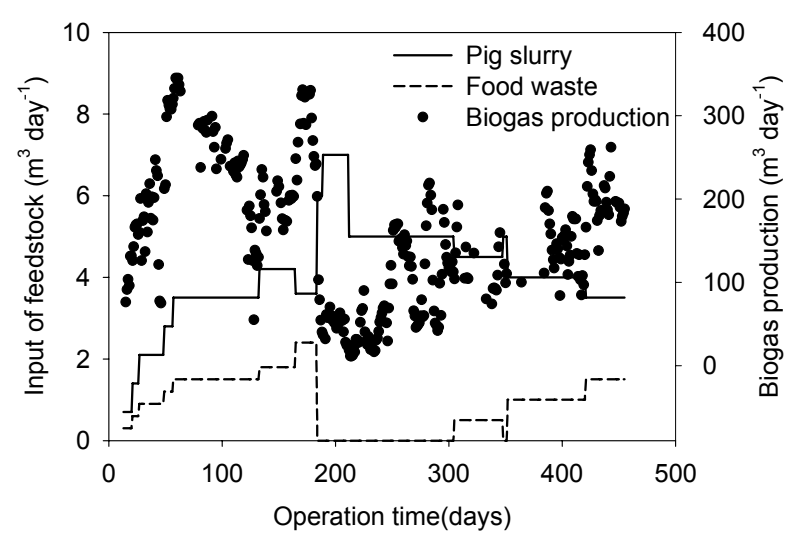

Fig. 5. Variation of biogas production in the pilot scale CSTR anaerobic digester.

total methane production was increased steeply.

During the start-up period (56 days) that has been stepwise increasing the input volume of food waste to $30 \%$ of total input volume, OLRs and methane yields in each step were shown in Fig. 6. OLRs at the 0, 10, 20, and $30 \%$ of total feedstock input volume were $1.201,1.254$, 1.345 , and $1.589 \mathrm{~kg}^{-} \mathrm{VS} \mathrm{m} \mathrm{day}^{-1}$, respectively. In the 0 , 10,20 , and $30 \%$ of total feedstock input volume, the upward tendency of biogas yields was investigated, methane yields of each step were $0.376,0.447,0.396$, and $0.588 \mathrm{~m}^{3}-\mathrm{CH}_{4} \mathrm{~kg}^{-1}-\mathrm{VS}_{\text {added. }}$. The methane yields were increased with the upward tendency of the operational OLR with the exception of the step of $20 \%$ food waste input. The occasional decrease of methane yield was caused in the high organic fluctuation of pig slurry that discharged from pig farmhouse. Fig. 7 showed the solid balance of anaerobic digester during the experimental period. Solid balance was calculated by the relative difference $\left[\left(\mathrm{S}_{0}-\mathrm{S}_{\mathrm{e}}\right)\right.$ $\left./ \mathrm{S}_{\mathrm{e}}\right]\left(\mathrm{S}_{0}\right.$ indicates VS content incoming to anaerobic digester, and $\mathrm{S}_{\mathrm{e}}$ indicates VS content of effluent in solid balance, in here, $S_{e}$ equals to the VS content of anaerobic digester) between the VS loading that was incoming to anaerobic digester and VS drawing off that was discharged from anaerobic digester by the effluent of digestate. 


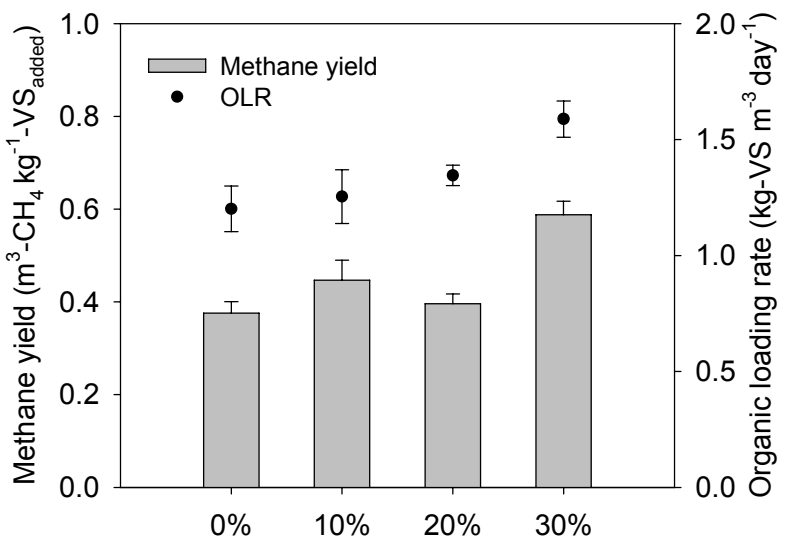

The input volume percentage of food waste

Fig. 6. Changes of methane yield in the different input ratio of food waste. Vertical bars mean the standard emors of each mean values.

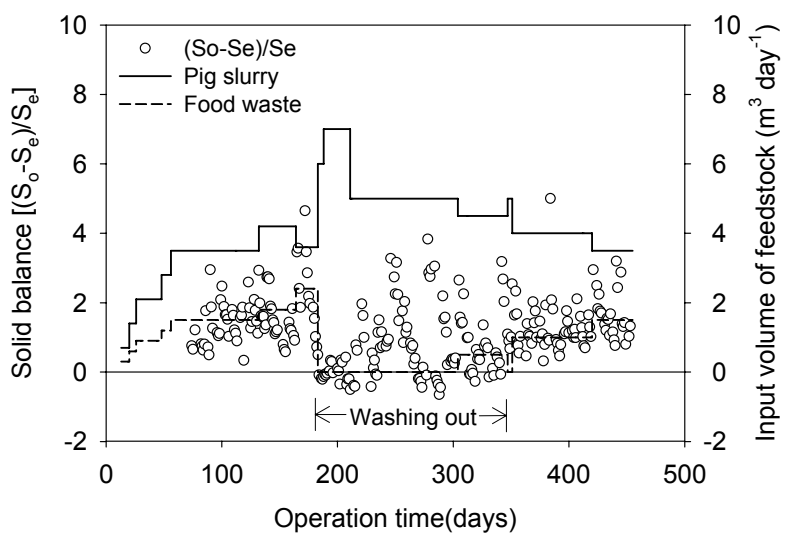

Fig. 7. Changes of solid balance in the pilot scale CSTR anaerobic digester. $S_{0}$ indicates VS content incoming to anaerobic digester, and $S_{e}$ indicates VS content of effluent in solid balance $\left[\left(S_{0}-S_{e}\right) / S_{e}\right]$.

Therefore the solid balance of anaerobic digester may imply the degree of "washing-out" that was caused by the fluctuation of input organic loading. In the operational Stage I and II that were fed with the mix of food waste, solid balance was monitored above zero, but some negative values for the solid balance of anaerobic digester occurred frequently in the Stage III that was operated and fed with only pig slurry. Digester performance of Stage III was more influenced by the variation of input organic loading than those of Stage I and II.

\section{Discussion}

This study showed the performance of co-digestion using the mixture (7:3) of pig slurry and food waste in the pilot scale CSTR anaerobic digester that was operated for 399 days after start-up. The anaerobic digester was designed with the OLR of $2.33 \mathrm{~kg}-\mathrm{VS} \mathrm{m}{ }^{-3}$ day $^{-1}$ and the HRT of 30 days, constructed with the concrete structure having the effective digester volume of $150 \mathrm{~m}^{3}$ in input scale of $5 \mathrm{~m}^{3}$ day $^{-1}$. In the design of biogas plant, TS and VS of anaerobic digester was 8.9 and $6.9 \%$, biogas yield was expected to be $199 \mathrm{Nm}^{3}$ day $^{-1}\left(\mathrm{CH}_{4} 60 \%\right)$ at VS degradation ratio of 53\% and methane yield of $0.34 \mathrm{Nm}^{3} \mathrm{~kg}^{-1}-\mathrm{VS}_{\text {added. }}$. This CSTR type digester was completely mixed as $5 \mathrm{rpm}$ with the peddle mixer in the interval of every 15 minutes. This digester adopts the design parameters of typical CSTR (Hartmann et al., 2000). After start-up of 56 days, digester fed with pig slurry mixed with food waste of $30 \%$, the operational OLR was in the range of $0.837-1.668 \mathrm{~kg}-\mathrm{VS}$ $\mathrm{m}^{-3}$ day $^{-1}$. And the methane yield, based on the mass of VS added, was $0.588 \mathrm{~m}^{3}-\mathrm{CH}_{4} \mathrm{~kg}^{-1}-\mathrm{VS}_{\text {addded }}$. VS degradation ratio was about $63 \%$. Biogas of 120.0 345.0 (average 252) $\mathrm{m}^{3}$ day $^{-1}$ was produced in the methane percentage of 65.669.8\%. Linke (1997) has reported that methane yields were $0.121 \mathrm{~m}^{3}-\mathrm{CH}_{4} \mathrm{~kg}^{-1}-\mathrm{VS}_{\text {added }}$ for pig slurry and $0.102 \mathrm{~m}^{3}-$ $\mathrm{CH}_{4} \mathrm{~kg}^{-1}-\mathrm{VS}_{\text {added }}$ for cattle manure, also other researchers reported the methane yield of $0.360 \mathrm{~m}^{3}-\mathrm{CH}_{4}{ }^{-1} \mathrm{~kg}$-VS added for pig slurry in the operation of CSTR type anaerobic digester (Hill and Bolte, 2000) and $0.230 \mathrm{~m}^{3}-\mathrm{CH}_{4} \mathrm{~kg}^{-1}$ $\mathrm{VS}_{\text {added }}$ for cattle manure in the operation of temperature phased anaerobic digester (Harikishan and Sung, 2003), respectively. Comparing with these reported results, the co-digestion of pig slurry and food waste can improve the performance of anaerobic digester. In this performance of digester, electricity production of $626 \mathrm{kWh}^{-1} \mathrm{day}^{-1}$ and heat recovery of $689 \mathrm{Mcal}^{\text {day }}{ }^{-1}$ were possible.

And in the operation of digester, high variations of operational OLR of digester were occurred due to the fluctuation of organic content in pig slurry discharged from pig farmhouse. But in spite of the fluctuation of organic content in pig slurry co-digestion with food waste that includes high amount of VS enabled to improve the biogas yield, and also methane content was able to be maintained in the range of $65.6-69.8 \%$ stably. When the digester fed with pig slurry was mixed with food waste of $40 \%$ (Stage II), although the OLR of feedstock showed more variation range of $1.220-3.524 \mathrm{~kg}-\mathrm{VS} \mathrm{m}{ }^{-3}$ day $^{-1}$ than that of $0.837-1.668 \mathrm{~kg}^{-V S ~ m}{ }^{-3}$ day $^{-1}$ in Stage I, anaerobic digester have stood with the impact by the high OLR variation. The biogas yield was increased to 222.5-330.2 $\mathrm{m}^{3}$ day $^{-1}$ maintaining the methane concentration of 61.4$68.0 \%$. In Stage III that fed with single pig slurry, biogas 
yield of digester was decreased to $11.3-170.0 \mathrm{~m}^{3}$ day ${ }^{-1}$. After co-digestion, the feeding of single pig slurry having low organic content and the organic variation of pig slurry discharged from the pig pan may cause "wash-out" that methane producing bacteria is lost from the anaerobic digester. It makes a microbial community of anaerobic digester to be imbalance, and in this case methane yield decrease steeply.

Generally most of Korean pig farmhouses have a high fluctuation in the organic contents since many pig pens have been adopting the slurry storage tank without a solid/ liquid separation. Therefore the co-digestion system is more adoptable to Korean pig farmhouse, co-digester can make farm scale anaerobic digester to keep up at more stable condition.

\section{Conclusions}

Single pig slurry anaerobic digestion co-digestion of pig slurry and food waste was investigated using CSTR pilot scale anaerobic digestion system. The performance of anaerobic digester was improved in co-digestion, the stability of anaerobic digester was more elevated sustaining the impact by the high OLR variation incoming to digester. Co-digestion of pig slurry and food waste has a synergistic effect which improves the biodegradation of feedstock. This effect resulted in higher methane yield than input of single pig slurry to digester. Especially in the case of Korean pig farmhouse that adopting the slurry storage tank without a solid/liquid separation, co-digestion of pig slurry and food waste affect was very effective method to advance the performance of anaerobic digester.

\section{Acknowledgements}

This work was carried out with the support of "Cooperative Research Program for Agricultural Science \& Technology Development (Project No. PJ006800201002)", Rural Development Administration, Republic of Korea.

\section{References}

Ahring, B.K. and I. Angelidaki. 2000. Methods for increasing the biogas potential from the recalcitrant organic matter contained in manure. Wat. Sci. Technol. 41(3):189-194.

Angelidaki, I. and L. Ellegaard. 2003. Codigestion of manure and organic wastes in centralized biogas plants. Appl. Biochem.
Biotech. 109:95-105.

Angelidaki, I., K. Boe, and L. Ellegaard. 2005. Effect of operation conditions and reactor configuration of efficiency of full-scale biogas plants. Wat. Sci. Technol. 52(1-2):189-194.

APHA. 1998. Standard Methods for the Examination of Water and Wastewater. $20^{\text {th }}$ ed. American Public Health Assoc. Washington, DC.

Azbar, N., P. Ursillo, and R.E. Speece. 2001. Effect of process configuration and substrate complexit on the performance of anaerobic processes. Wat. Res. 35 (3):817-829.

Boe, K. and I. Angelidaki. 2009. Serial CSTR digester configuration for improving biogas production from manure. Wat. Res. 43:166-172

Bouallagui, H., H. Lahdheb, E.B. Romdan, B. Rachdi, and M. Hamdi. 2009. Improvement of fruit and vegetable waste anaerobic digestion performance and stability with co-substrates addition. J. Environ. Manag. 90:1844-1849.

Callaghan, F.J., D.A. Wase, J.K. Thayanithy, and C.F. Foster. 1999. Co-digestion of waste organic solids: batch studies. Bioresour. Technol. 67:117-122.

Hansen, K.H., I. Angelidaki, and B.K. Ahring. 1998. Anaerobic digestion of swine manure: inhibition by ammonia. Wat. Res. 32(1):5-12.

Harikishan, S. and S. Sung. 2003. Cattle waste treatment and Class A biosolid production using temperature-phased anaerobic digester. Adv. Environ. Res. 7:701-706.

Hartmann, H., I. Angelidaki, and B.K. Ahring. 2000. Increase of anaerobic degradation of particulate organic matter in full-scale biogas plants by mechanical maceration. Wat. Sci. Technol. 41:145-153

Hartmann, H., I. Angelidaki, and B.K. Ahring. 2000. Increase of anaerobic degradation of particulate organic matter in fullscale biogas plants by mechanical maceration. Wat. Sci. Technol. 41:145-153.

Hill, D.T. and J.P. Bolte. 2000. Methane production from low solid Concentration liquid swine waste using conventional anaerobic fermentation. Bioresour. Technol. 74:241-247.

Karakashev, D., D.J. Batstone, and I. Angelidaki. 2005. Influence of the environmental conditions on the methanogenic composition of anaerobic biogas reactors. Appl. Environ. Microbiol. 71: 331-338.

Kramer, J. 2004. “Agricultural Biogas Casebook-2004 Update.” Great Lakes Regional Biomass Energy Program, Council of Great Lakes Governors.

Linke, B. 1997. A model for anaerobic digestion of animal waste slurries . Environ. Technol. 18:849-854.

Paavola, T., E. Syväsalo, and J. Rintala. 2006. Co-digestion of manure and biowaste according to the $\mathrm{EC}$ animal by-products regulation and Finnish national regulation. Wat. Sci. Technol. 53(8):223-231.

Poggi-Varaldo, H.M., L. Valdes, F. Esparza-Garcia, and G. FenandezVillagomez. 1997. Solid substrate anaerobic co-digestion of paper mill sludge, biosolids, and municipal solid waste. Wat. Sci. Technol. 35:197-204.

Sorensen, A.H., M. Winther-Nielsen, and B.K. Ahring. 1991. Kinetics of lactate, acetate and propionate in unadapted and 
lactate-adapted thermophilic, anaerobic sewage sludge: the influence of sludge adaptation for start-up of thermophilic UASB-reactors. Microbiol. Biotechnol. 34:823-827.

Speece, R.E., M. Duran, G. Demirer, H. Zhang, and T. Distefano. 1997. The role of process configuration in the performance of anaerobic systems. Wat. Sci. Technol. 36:539-547.

Wilkie, A.C., H.F. Castro, K.R. Cubisnki, J.M. Owens, and S.C. Yan. 2004. Fixed-film anaerobic digestion of flushed dairy manure after primary treatment: wastewater production and characterization. Biosystems. 89(4):457-471.

Yoon, Y.M., C.H. Kim, Y.J. Kim, and H.T. Park. 2009 . The economical evaluation of biogas production facility of pig waste. Kor. J. Agr. Manag. Pol. 36(1):137-157.

Yoon, Y.M., Y.J. Kim, and C.H. Kim. 2009 ${ }^{b}$. The evaluation of economical efficiency to composting and liquefying process of biomass discharged in pig breeding. Agr. Econ. 31(6):39-62. Yu, Y., C. Lee, and S. Hwang. 2005. Analysis of community structures in anaerobic processes using a quantitative realtime PCR method. Wat. Sci. Technol. 52(1-2):85-91.

Zhang, Y. and C.J. Banks. 2008. Optimizing inputs and outputs from anaerobic digestion processes by co-digestion of municipal waste streams with wastes from commercial, industrial and agricultural sectors. In: Proceedings of the Fifth ISAd-sw. 24-28 May, hammamet, Tunisia. 